\title{
Late Preterm Infant Diagnosed with Thrombocytopenia Absent Radius Syndrome
}

\section{Geç Preterm Bir Yenidoğanda Tanı Alan Trombositopeni Radius Yokluğu Sendromu}

\author{
Övgü Büke, Sultan Bent, Tuğçe Damla Türkpençe, Şahin Hamilçıkan, Emrah Can \\ University of Health Sciences, Bağcılar Training and Research Hospital, Clinic of Pediatrics, Istanbul, Turkey
}

\begin{abstract}
Thrombocytopenia absent radius (TAR) syndrome is a rare genetic anomaly presenting with bilateral radial aplasia and thrombocytopenia. Pathophysiology is not fully understood. Patients may need to receive thrombocyte transfusions for better neurological outcome and frequent followup may prevent serious complications such as intracranial hemorrhage. Here we report a one-day-old late preterm neonate diagnosed with TAR syndrome by clinical and laboratory data, and confirmed by genetic studies.

Keywords: Thrombocytopenia absent radius, thrombocytopenia, radius, neonate, preterm
\end{abstract}

ÖZ

Trombositopeni radius yokluğu (TAR) sendromu, nadir görülen bilateral radius yokluğu ve trombositopeni ile karakterize bir sendromdur. Patofizyolojisi tam olarak anlaşılamamıştır. Hastalar nörolojik gelişimlerinin etkilenmemesi ve intrakraniyal kanama gibi izlemde gelișebilecek komplikasyonlardan korunmak için trombosit transfüzyonuna gereksinim duyabilirler. Burada bir günlük geç preterm bir yenidoğanda klinik ve laboratuvar olarak tanı konulan ve genetik çalışmalar ile konfirme edilen TAR sendromu olgusu sunulmuştur. Anahtar Kelimeler: Trombositopeni radius yokluğu, trombositopeni, radius, yenidoğan, prematüre

\section{Introduction}

Thrombocytopenia absent radius (TAR) syndrome is a rare genetic condition, characterized by bilateral absence of the radii while both thumbs are present, and thrombocytopenia. Skeletal, hematologic, and cardiac system involvement may also occur. Incidence of TAR syndrome is 0.42 per 100000 births. Intracranial hemorrhages due to thrombocytopenia or serious cardiac defects are often the cause of death (1). Mental retardation may develop secondary to intracranial hemorrhage (2). Epilepsy, learning difficulties, intracranial vascular malformations, sensorineural hearing loss, hypoplasia of corpus callosum and cerebellar dysgenesis have been reported as associated neurological abnormalities. Although primordial megakaryocytes are suspected to take part in pathogenesis due to their role in formation of blood vessels, the mechanism leading to this congenital phenomenon is not fully understood (3).

Herein we report a late preterm one-day-old neonate diagnosed with TAR syndrome by clinical and laboratory data, and confirmed by genetic studies.

\section{Address for Correspondence/Yazısma Adresi}

Emrah Can MD, University of Health Sciences, Bağcllar Training and Research Hospital, Clinic of Pediatrics, Istanbul, Turkey

Phone: +905325123606 E-mail: canemrahcan@yahoo.com

Received/Geliş tarihi: 15.02.2016 Accepted/Kabul tarihi: 14.04.2016

${ }^{\circ}$ Copyright 2017 by Ege University and Ege Children's Foundation

The Journal of Pediatric Research, published by Galenos Yayınevi. 


\section{Case Report}

A 36 5/7-week gestation male infant, with a birth weight of 2600 grams, was born by normal vaginal delivery to a 28-year-old Syrian mother and admitted to neonatal intensive care unit for upper limb hypoplasia. Detailed prenatal history was absent due to communication issues.

Physical examination revealed radially deviated upper limbs with no thumb deformity but hypoplastic fingers. There were no deformities in the lower limbs other than laterally deviated bilateral halluces (Figure 1). Abdominal examination revealed no organomegaly. On cardiac auscultation, a soft (2/6) systolic murmur was heard over the left sternal side.

Complete blood count showed white cell count of 29800/ $\mathrm{mm}^{3}$ and platelet count of $36000 / \mathrm{mm}^{3}$. Other laboratory

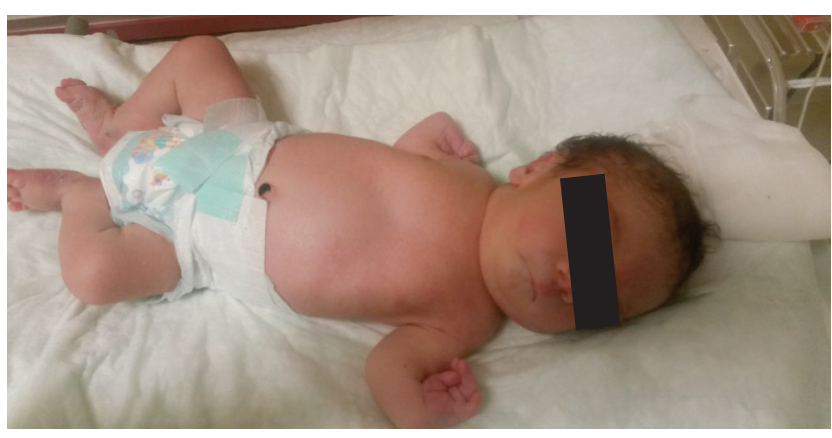

Figure 1. General appearance of the patient

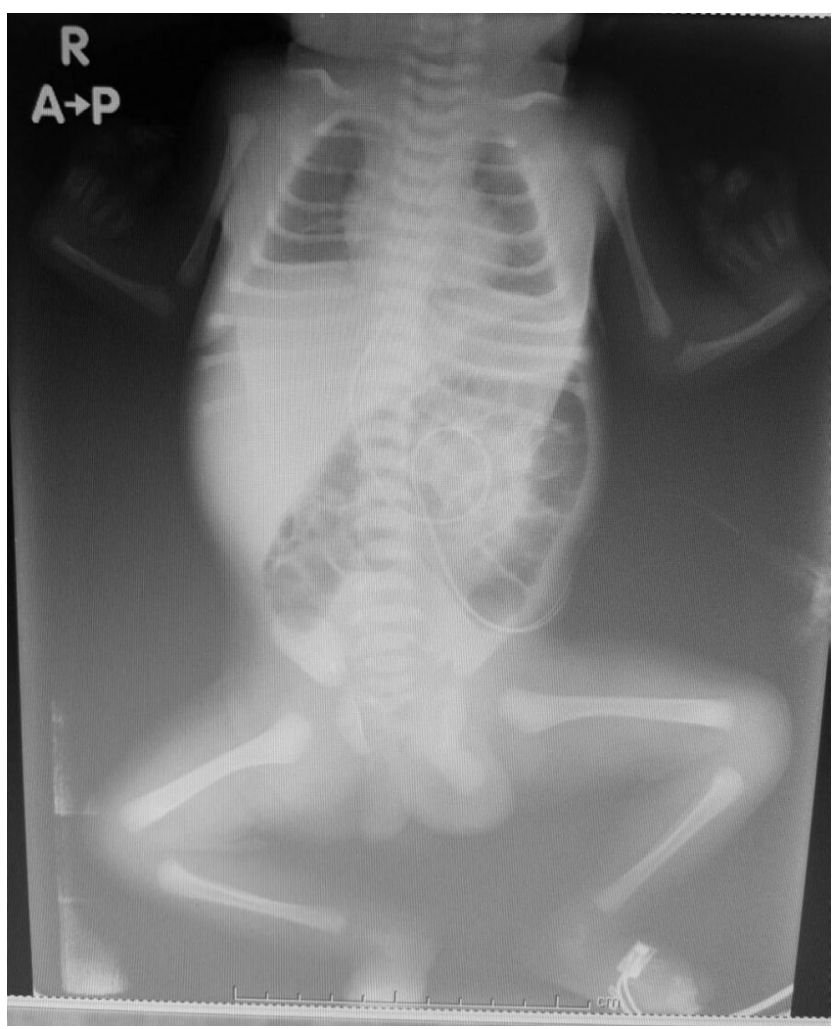

Figure 2. On the $\mathrm{X}$ ray-graphy, absence of bilateral radius was shown results were within normal ranges. Radiography of forearms revealed bilateral absence of radii (Figure 2). Echocardiography was performed, which showed ventricular septal defect (VSD), patent ductus arteriosus (PDA), atrial septal defect (ASD) and pulmonary hypertension. Transcranial and abdominal ultrasonography were normal. The patient was administered platelet transfusion when complete blood count revealed that the platelet count was below $25000 / \mathrm{mm}^{3}$. Platelet levels increased to $129000 / \mathrm{mm}^{3}$ following transfusion. Monitoring the case continues in the postnatal $3^{\text {rd }}$ month.

\section{Discussion}

Thrombocytopenia associated with TAR syndrome is believed to be related to a process of defective megakaryopoiesis resulting from a faulty progenitor cell. Patients usually become symptomatic within the first 4 months of life, and deaths from intracranial hemorrhages often occur in this period $(2,4)$. In a previously published case series of 77 patients, overall mortality rate was $27 \%$ and of these, 21 deaths (66.6\%) occurred within the first four months, $28.5 \%$ in between $4-14$ months, and $4.7 \%$ after one month (5). Episodes of thrombocytopenia often are triggered by infections, surgical interventions and in some cases, after ingestion of cow's milk. Episode intervals become less frequent, and the severity of the attacks decreases by the time patient reaches the age of two. In our case, the patient received platelet transfusion when severe thrombocytopenia was detected in order to prevent complications.

Leukemoid reaction triggered by stress and infections may occur mostly within the first year of life (6). Leukocyte levels can increase up to $35000 / \mathrm{mm}^{3}$. Thrombocytopenia may worsen and hepatomegaly can be detected on physical examination (3). We didn't determine leukemoid reaction in the laboratory analysis of our case.

Pathophysiology of anemia, developing in the patients with TAR syndrome within the first year of life, is not clear. It may be due to hemolysis, thrombocytopenia related blood loss, or short lifespan of the erythrocytes (3). We neither observed symptoms related to anemia, nor determined abnormal laboratory analysis in the reported case. The most important skeletal abnormality detected in TAR syndrome is bilateral radius hypoplasia. Autopsy findings have shown that patients have normally attached muscles to carpal bones, and they always have both thumbs and fingers. Upper extremity anomalies associated with TAR syndrome include hypoplastic ulna, hypoplastic humerus and syndactyly. In the reported case, bilateral radii were absent and the hands were deviated toward ulna, but there was no finger abnormality. Abnormalities associated with the lower extremity in TAR syndrome are mild $(5,7)$. In the reported patient, we did not observe pathological findings related to lower limbs, except laterally deviated halluces. The ratio of cardiac problems is $30 \%$ among patients with TAR syndrome, and the most common heart defects are tetralogy of Fallot (17.6\%), ASD (17.6\%), and VSD (17.6\%). Echocardiographic evaluation 
of our case revealed VSD, PDA, ASD, and pulmonary hypertension.

Hedberg and Lipton (5) showed that TAR syndrome has $18 \%$ mortality and the most common causes of death include hemorrhages (88.8\%) (intracranial, visceral, and pulmonary), sepsis (5.5\%), and congestive heart failure (5.5\%).

TAR syndrome can be diagnosed antenatally after 16 weeks of gestation by fetoscopy, X-rays and ultrasonography (8). In our case, the mother had no follow-up during pregnancy. When diagnosed, patients with TAR syndrome should be monitored closely and collaboration should be made with an orthopedics department. Life expectancy is reported normal with successful follow-up. The treatment of thrombocytopenia is also important to prevent complications, and thrombocyte transfusion is necessary when values reach critical level.

\section{Ethics}

Informed Consent: Written informed consent was declared by the authors.

Peer-review: Externally peer-reviewed.

\section{Authorship Contributions}

Surgical and Medical Practices: Ö.B., T.D.T., Ş.H., Design: E.C., Ö.B., T.D.T., Data Collection or Processing: Ö.B., S.B., Literature Search: S.B., S.H., Writing: T.D.T., E.C.

Conflict of Interest: No conflict of interest was declared by the authors.
Financial Disclosure: The authors declared that this study has received no financial support.

\section{References}

1. Kumar C, Sharma D, Pandita A, Bhalerao S. Thrombocytopenia absent radius syndrome with Tetralogy of Fallot: a rare association. Int Med Case Rep J 2015;8:81-5.

2. McLaurin TM, Bukrey CD, Lovett RJ, Mochel DM. Management of thrombocytopenia-absent radius (TAR) syndrome. J Pediatr Orthop 1999;19:289-96.

3. Hall JG. Thrombocytopenia and absent radius syndrome. J Med Genet 1987;24:79-83.

4. Labrune P,Pons JC, Khalil M, etal. Antenatal thrombocytopenia in three patients with TAR (thrombocytopenia with absent radii) syndrome. Prenat Diagn 1993;13:463-6.

5. Hedberg VA, Lipton JM. Thrombocytopenia with absent radii. A review of 100 cases. Am J Pediatr Hematol Oncol 1988; 10:51-64.

6. Teufel M, Enders $H$, Dopfer R. Consanguinity in a Turkish family with thrombocytopenia with absent radii (TAR) syndrome. Hum Genet 1983;64:94-6.

7. Fromm B, Niethard FU, Marquardt E. Thrombocytopenia and absent radius (TAR) syndrome. Int Orthop 1991;15:95-9.

8. Gounder DS, Pullon HW, Ockelford PA, Nicol RO. Clinical manifestations of the thrombocytopenia and absent radii (TAR) syndrome. Aust N Z J Med 1989;19:479-82. 